\title{
VEGF serum concentration and irreversible bronchoconstriction in adult asthmatics
}

\author{
Krzysztof Gomułka ${ }^{1, A, B, D}$, Jerzy Liebhartt ${ }^{1, F}$, Urszula Gładysz ${ }^{2, C}$, Wojciech Mędrala, ${ }^{1, E}$ \\ 1 Department of Internal Medicine and Allergology, Wroclaw Medical University, Poland \\ ${ }^{2}$ Institute of Informatics, University of Wrocław, Poland \\ A - research concept and design; B - collection and/or assembly of data; $C$ - data analysis and interpretation; \\ $D$ - writing the article; $E$ - critical revision of the article; $F$ - final approval of the article
}

\section{Address for correspondence \\ Krzysztof Gomułka \\ E-mail: krzysztof.gomulka@umed.wroc.pl \\ Funding sources \\ This study was supported by the grant \\ for young scientists No. Pbmn 150 \\ from Wroclaw Medical University in Poland \\ (granted to Krzysztof Gomułka).}

\section{Conflict of interest}

None declared

\section{Acknowledgements}

The authors thank Barbara Majewska for per-

forming spirometry tests and Emilia Królewicz

for laboratory analyses.

Received on 0ctober 22, 2017

Reviewed on February 1, 2018

Accepted on June 6, 2018

Published online on February 8, 2019

Cite as

Gomułka K, Liebhart J, Gładysz U, Mędrala W. VEGF

serum concentration and irreversible bronchoconstriction in adult asthmatics. Adv Clin Exp Med. 2019;28(6):759-763. doi:10.17219/acem/92012

DOI

10.17219/acem/92012

\section{Copyright}

Copyright by Author(s)

This is an article distributed under the terms of the

Creative Commons Attribution Non-Commercial License

(http://creativecommons.org/licenses/by-nc-nd/4.0/)

\begin{abstract}
Background. Vascular endothelial growth factor (VEGF) is an angiogenic, heparin-binding glycoprotein playing an important role in the pathogenesis of many diseases and disorders, including asthma. It has been reported that increased VEGF serum concentration is a biomarker of neovascularization, which could suggest that higher VEGF expression may be relevant to asthmatics with airway remodeling and irreversible bronchoconstriction.
\end{abstract}

Objectives. The aim of this study was to assess the possible association between VEGF serum concentration and irreversible bronchoconstriction in adult patients with a diagnosis of asthma.

Material and methods. This study involved 82 adult patients with asthma (42 persons with and 40 persons without irreversible bronchoconstriction) and 40 healthy adult controls. Vascular endothelial growth factor serum concentration was analyzed using enzyme-linked immunosorbent assay (ELISA).

Results. Vascular endothelial growth factor serum concentration in patients with asthma was higher than in healthy controls $(p=0.0131)$, particularly in those from the subgroup of irreversible bronchoconstriction ( $p=0.0133$ ). The rising tendency was confirmed using the Kruskal-Wallis rank sum test that showed a significant difference $(p=0.0374)$ in VEGF values among the 3 groups examined: healthy controls $(\mathrm{Me}=246.6 \mathrm{pg} / \mathrm{mL})$, asthmatics with reversible bronchoconstriction $(\mathrm{Me}=288.6 \mathrm{pg} / \mathrm{mL})$ and asthmatics with irreversible bronchoconstriction ( $\mathrm{Me}=340.6 \mathrm{pg} / \mathrm{mL}$ ). However, the direct comparison between the 2 asthmatics groups (reversible vs irreversible bronchoconstriction) did not show a statistically significant difference $(p=0.5521)$.

Conclusions. Increased VEGF serum concentration is characteristic of patients with asthma, especially those with irreversible bronchoconstriction.

Key words: asthma, vascular endothelial growth factor, remodeling, bronchoconstriction 


\section{Introduction}

Vascular endothelial growth factor (VEGF) is a dimeric, heparin-binding glycoprotein with a molecular weight of $46 \mathrm{kDa}$. The VEGF family consists of several members, e.g.: VEGF-A (discovered first and called just VEGF), VEGF-B, VEGF-C, VEGF-D, and placenta growth factor (PGF). The VEGF gene has the chromosomal locus on 6 p21.3 and contains a 14-kb coding region with 8 exons and 7 introns. Splicing of a single gene results in transcription of VEGF variants with different numbers of amino acids identified in human cells. Among them, VEGF 121 and VEGF $_{165}$ are secreted as soluble forms, whereas VEGF $_{189}$ and VEGF $_{206}$ are associated with the cells' surface. $^{1,2}$ Primarily, VEGF is expressed in epithelial cells, platelets, neutrophils, and macrophages. The biological activity of VEGF is dependent on interaction between soluble forms of this glycoprotein and one of the receptors (VEGF-R1, VEGF-R2 or VEGF-R3) that are mainly expressed in endothelial cells, activated macrophages and epithelial cells. Receptors for VEGF belong to the tyrosine kinase receptors which, after VEGF-stimulation, dimerize and become activated through transphosphorylation. ${ }^{3}$ Vascular endothelial growth factor seems to specifically affect endothelial cells' growth, survival and permeability, and moreover, it enhances vascular permeability, modulates thrombogenicity, protects endothelial cells against apoptosis and delays endothelial cell senescence. ${ }^{4,5}$

Previous studies have reported that increased mean VEGF serum concentration may be related to tissue hypoxia and inflammation during age-related macular degeneration, ${ }^{6}$ rheumatoid diseases, ${ }^{7}$ sepsis, ${ }^{8}$ coronary heart disease, ${ }^{9}$ chronic obstructive pulmonary disease (COPD), ${ }^{10}$ and cancers. ${ }^{11,12}$ For this reason, the peripheral VEGF levels have been considered as a biomarker of neovascularization and vascular remodeling. Hypoxia as well as inflammation are also relevant to asthma - therefore the biological properties of VEGF have led to interest of this molecule within the lung, suggesting that the higher expression of VEGF may play a potential role in the pathogenesis of asthma and lung remodeling. ${ }^{13-15}$ Vascular endothelial growth factor can promote proliferation of airway smooth muscle (ASM) cells. It upregulates disintegrin and metalloproteinase (ADAM-33) mRNA and protein levels in a doseand time-dependent manner as well as phosphorylation of phospho-extracellular signal-regulated kinase $1 / 2$ (ERK1/2) and phospho-Akt (Akt). ${ }^{16}$ In addition, longitudinal analysis performed in a study by the Childhood Asthma Management Program (CAMP) showed an association of the rs4711750 VEGF genotype with $\mathrm{FEV}_{1} / \mathrm{FVC}$ decline over 4.5 years of observation. ${ }^{17}$

Despite the existence of such strong indications that VEGF may play an important role in the asthma pathomechanism and the development of airway remodeling, we have not found in the available literature any report on the possible connection of VEGF serum concentration with irreversible bronchoconstriction in adult asthmatics. Therefore, the aim of the present study was to compare VEGF serum concentrations in asthmatics and healthy individuals and to assess whether they were associated with irreversible bronchoconstriction.

\section{Material and methods}

The study sample consisted of 122 participants (42 male) aged 20-70 years, of whom 40 subjects (14 male) did not manifest any allergies and had normal pulmonary function. Among this control group, 11 participants had a positive history toward smoking. In a group of 82 patients (28 male) aged 23-69 years, the diagnosis of asthma was established according to the Global Initiative for Asthma (GINA) recommendations. Patients diagnosed with ACO (asthma-COPD overlap) were excluded from our study. The degree of severity of asthma ranged from sporadic to severe and persistent. On the basis of the bronchodilation test, asthmatics were divided into 2 subgroups: patients with irreversible bronchoconstriction (42 patients, 17 male, aged 24-69 years) and patients without irreversible bronchoconstriction (40 patients, 11 male, aged 23-69 years). In the asthmatics with reversible bronchoconstriction, 6 patients had positive smoking history, 27 participants used inhaled corticosteroids (budesonide or fluticasone propionate), 28 patients were treated with long-acting $\beta 2$ agonists (salmeterol or formoterol fumarate), and 38 patients declared using short-acting $\beta 2$ agonists "on demand" (salbutamol or fenoterol hydrobromide + ipratropium bromide). Among the asthmatics with irreversible bronchoconstriction, 15 patients had positive smoking history, 37 participants used inhaled corticosteroids (budesonide or fluticasone propionate), 38 patients were treated with long-acting $\beta 2$ agonists (salmeterol or formoterol fumarate), and 42 patients declared using short-acting $\beta 2$ agonists "on demand" (salbutamol or fenoterol hydrobromide + ipratropium bromide). The population data is shown in Table 1.

The study protocol was approved by the Ethics Committee of Wroclaw Medical University, Poland.

\section{Bronchodilation test}

The pulmonary function test and bronchodilation test, specifying forced vital capacity (FVC) and forced expiratory volume in $1 \mathrm{~s}$ (FEV1) values, were performed using a MasterScope CT Spirometer (Erich Jaeger GmbH, Würzburg, Germany). The bronchodilation test was performed after inhalation with $5 \mathrm{mg}$ of salbutamol (SteriNeb Salamol; Teva Pharmaceuticals, Warszawa, Poland) administered with a jet nebulizer (Model 4650-U; Devilbiss, Heston, UK). The postbronchodilator values of FEV1/FVC $<0.7$ and FEV $1<80 \%$ predicted were taken as a criterion of irreversible bronchoconstriction. 
Table 1. Characteristics of study population

\begin{tabular}{|c|c|c|c|}
\hline Parameter & $\begin{array}{c}\text { Asthmatics } \\
\text { - irreversible bronchoconstriction }\end{array}$ & $\begin{array}{c}\text { Asthmatics } \\
\text { - reversible bronchoconstriction }\end{array}$ & Controls \\
\hline$n$ & 42 & 40 & 40 \\
\hline Male gender & $17(40.48 \%)$ & $11(27.5 \%)$ & $14(35 \%)$ \\
\hline Age [years], $\bar{x} \pm S D$ & $53.71 \pm 10.40$ & $50.03 \pm 13.65$ & $47.95 \pm 13.66$ \\
\hline Age [years], Me (min-max) & $55(24-69)$ & $52(23-69)$ & $52.5(20-70)$ \\
\hline Disease duration [mean years] & 21.94 & 10.04 & - \\
\hline $\mathrm{FVC} \%, \overline{\mathrm{x}} \pm \mathrm{SD}$ & $72.21 \pm 19.31$ & $98.49 \pm 13.89$ & $101.36 \pm 13.26$ \\
\hline $\mathrm{FEV} 1 \%, \bar{x} \pm \mathrm{SD}$ & $56.05 \pm 18.62$ & $90.12 \pm 17.25$ & $104.81 \pm 15.37$ \\
\hline $\mathrm{FEV} 1 / \mathrm{FVC}, \overline{\mathrm{x}} \pm \mathrm{SD}$ & $0.61 \pm 0.11$ & $0.73 \pm 0.10$ & $0.82 \pm 0.06$ \\
\hline Smoking (answer "yes") & $15(35.71 \%)$ & $6(15 \%)$ & $11(27.5 \%)$ \\
\hline inhGKS & $37(88.1 \%)$ & $27(67.5 \%)$ & - \\
\hline LABA & $38(90.48 \%)$ & $28(70 \%)$ & - \\
\hline SABA "on demand" & $42(100 \%)$ & $38(95 \%)$ & - \\
\hline
\end{tabular}

$\bar{x}$ - mean; SD - standard deviation; Me - median; min-max - minimum-maximum; FVC\% - forced vital capacity, \% of predicted; FEV1\% - forced expiratory volume in $1 \mathrm{~s}$, \% of predicted; inhGKS - inhaled corticosteroids; LABA - long-acting beta-2 agonists; SABA - short-acting beta-2 agonists.

\section{VEGF serum concentration}

To estimate the mean VEGF serum concentration, the "sandwich" enzyme-linked immunosorbent assay (ELISA) was used. The VEGF concentration was measured in $\mathrm{pg} / \mathrm{mL}$ and the Quantikine Human VEGF Immunoassay Kit was used according to the recommendation of the manufacturer. The minimum detectable VEGF concentration was no less than $5.0 \mathrm{pg} / \mathrm{mL}$. Individual blood samples were assayed twice and the average value was taken for further analysis. The normal values of VEGF serum concentration extend from $62.0 \mathrm{pg} / \mathrm{mL}$ to $707.0 \mathrm{pg} / \mathrm{mL}$.

\section{Statistical analysis}

Statistical analysis was performed using the STATISTICA v. 10 for Windows statistical program (StatSoft Inc., Tulsa, USA). Data distribution was evaluated using the Shapiro-Wilk W test. Nonparametric statistics were used for variables without normal distribution. The data was analyzed using descriptive statistics methods and KruskalWallis and Mann-Whitney U tests. A p-value $<0.05$ was considered statistically significant.

\section{Results}

Statistical analyses (Tables 2, 3) showed that VEGF serum concentration in all patients with asthma was higher than in healthy controls $(\mathrm{p}=0.0131$; odds ratio $(\mathrm{OR})=2.38$; $95 \%$ confidence interval $(95 \% \mathrm{CI})=1.00-5.69)$, particularly in those from the subgroup of irreversible bronchoconstriction ( $\mathrm{p}=0.0133$; OR $=3.48 ; 95 \% \mathrm{CI}=0.62-4.67$ ). The increasing tendency was confirmed with the KruskalWallis rank sum test that showed a significant difference $(p=0.0374)$ in VEGF values among the 3 groups examined:
Table 2. VEGF serum concentrations $[\mathrm{pg} / \mathrm{mL}$ ] in the study sample

\begin{tabular}{|l|c|}
\multicolumn{1}{|c|}{ Examined groups } & \multicolumn{1}{c|}{$\begin{array}{c}\text { Me } \\
\text { (min-max) }\end{array}$} \\
\hline $\begin{array}{l}\text { Asthmatics } \\
\text { - irreversible bronchoconstriction }\end{array}$ & 340.65 \\
\hline Asthmatics & $(85.9-1,470.0)$ \\
- reversible bronchoconstriction & 288.6 \\
Asthmatics & $(71.7-1,134.0)$ \\
- whole examined group & 314.35 \\
\hline Controls & $(71.7-1,470.0)$ \\
\hline
\end{tabular}

Me-median; min-max-minimum-maximum

Table 3. Comparisons of VEGF serum concentration $[\mathrm{pg} / \mathrm{mL}]$ between groups examined

\begin{tabular}{|l|c|}
\multicolumn{1}{|c|}{ Compared groups } & p-value \\
\hline $\begin{array}{l}\text { Asthmatics with irreversible bronchoconstriction vs } \\
\text { asthmatics with reversible bronchoconstriction vs controls }\end{array}$ & $0.0374 \#$ \\
\hline $\begin{array}{l}\text { Asthmatics with reversible bronchoconstriction vs controls } \\
\text { Asthmatics with irreversible bronchoconstriction vs } \\
\text { controls }\end{array}$ & $0.0705^{*}$ \\
\hline $\begin{array}{l}\text { Asthmatics with irreversible bronchoconstriction vs } \\
\text { asthmatics with reversible bronchoconstriction }\end{array}$ & $0.0133^{*}$ \\
\hline Asthmatics/whole examined group/vs controls & $0.5221^{*}$ \\
\hline
\end{tabular}

* - Mann-Whitney U test; \# - Kruskal-Wallis ANOVA test.

healthy controls (median $(\mathrm{Me})=246.6 \mathrm{pg} / \mathrm{mL})$, asthmatics with reversible bronchoconstriction $(\mathrm{Me}=288.6 \mathrm{pg} / \mathrm{mL})$ and asthmatics with irreversible bronchoconstriction $(\mathrm{Me}=340.6 \mathrm{pg} / \mathrm{mL})$. However, the direct comparison between the 2 latter groups (asthmatics with reversible vs irreversible bronchoconstriction) did not show a statistically significant difference $(\mathrm{p}=0.5521$; OR $=2.05 ; 95 \%$ $\mathrm{CI}=0.67-6.39)$. Spearman's rank correlation coefficient did 
not show any significant difference in asthmatics between VEGF serum concentration and spirometric values (FVC\%, FEV1\% and FEV1/FVC) and between the age of patients and FEV1\% value. The comparison between asthmatics with and without irreversible bronchoconstriction and with positive smoking history showed a statistically significant difference $(\mathrm{p}=0.0317$; OR $=3.15 ; 95 \% \mathrm{CI}=0.97-10.62)$.

\section{Discussion}

Vascular endothelial growth factor was first described in 1983 by Senger et al. as the vascular permeability factor (VPF) secreted by tumor cells. ${ }^{18}$ Its protein structure and significance were later identified by Ferrara and Henzel. ${ }^{19}$ Since then, several studies have also investigated circulating VEGF levels in patients with asthma, indicating its role in inflammation and neovascularization. ${ }^{20-22}$ The clinical picture of asthma depends on a variety of factors, probably including (among other things) the VEGF gene polymorphism. ${ }^{15}$ Significant differences in VEGF concentration between patients with asthma and controls have been shown not only in induced sputum, but also in bronchoalveolar lavage or bronchial biopsies. ${ }^{23,24}$ The authors observed higher overall levels of VEGF in samples taken from patients with asthma. The findings also suggest the influence of VEGF on the hyperactivity of airways and reduction of bronchial diameter by thickening the bronchial wall during the remodeling process. In a previous study, Barbato et al. ${ }^{25}$ observed an inverse correlation between FEV1 values and the number of vessels in the lamina propria of airways in patients with asthma and atopy. Results obtained by Abdel-Rahman et al. ${ }^{26}$ showed that VEGF concentration is increased and proportional to the severity of asthma in children during exacerbations of asthma associated with respiratory tract infection. The results of the current study have shown that VEGF serum concentrations are elevated in patients with asthma, especially in those with irreversible bronchoconstriction. However, the difference between the groups with reversible and non-reversible bronchoconstriction was not statistically significant, which could be partly attributed to the relatively small sample size.

It has been known that VEGF levels may depend on, among others, status of smoking, the effect of inhaled corticosteroids, duration of asthma, or eosinophilic inflammatory profiles. ${ }^{27}$ According to the Global Initiative for Asthma (GINA) report, ${ }^{28}$ cigarette smoking is a modifiable risk factor connected with asthma exacerbation and persistence of airway obstruction. The results obtained confirm that a positive history toward smoking promotes the development of irreversible bronchoconstriction in asthmatics. However, smoking cannot be regarded as a single and dominant factor for remodeling because the majority of asthmatics with irreversible bronchoconstriction have never smoked. In the groups examined, a relationship between therapy with inhaled corticosteroids and degree of bronchoconstriction was not revealed. In asthmatics, treatment with inhaled corticosteroids was declared mostly in the group with irreversible bronchoconstriction, which suggests that inhaled corticosteroids may delay the progression of airway remodeling but is unable to effectively prevent bronchoconstriction. Another factor that may correlate with the VEGF level and severity of remodeling in the airways is the asthma duration. In our study, longer duration of asthma was demonstrated in patients with irreversible bronchoconstriction, which seems to confirm that for remodeling connected with irreversible airway narrowing, the duration of the disease also should be taken into account. On the other hand, it is difficult to determine the influence of the sex and age of the patients examined on the severity of the remodeling and bronchoconstriction, as the percentage of women and men was similar and the median age and age range of patients in the examined groups were similar. A limitation in our study was not taking into account the atopic status of patients, family history toward allergy, place of living (city or village), additional diseases (e.g., pulmonary and cardiac failure), or the number of eosinophils. Also, the measurements of bronchial wall thickness using computed tomography (CT) were not performed. This issue is undoubtedly worth conducting further extensive studies because VEGF seems to be an emerging target for novel asthma therapies. It should be noted that several anti-VEGF drugs are already available (e.g., ranibizumab or bevacizumab), licensed for use in various diseases (mainly in oncological disorders and eye diseases). ${ }^{29,30}$

\section{References}

1. Ferrara N, Gerber HP, LeCouter J. The biology of VEGF and its receptors. Nat Med. 2003;9(6):669-676.

2. Gomułka K, Liebhart J. Vascular endothelial growth factor: Structure, function and role in airways inflammation and the clinical course of asthma [in Polish]. Pneumonol Alergol Pol. 2009;77(6):549-553.

3. Gover-Proaktor A, Granot G, Shapira S, et al. Ponatinib reduces viability, migration, and functionality of human endothelial cells. Leuk Lymphoma. 2017;58(6):1455-1467.

4. Yamamoto $H$, Rundqvist $H$, Branco $C$, Johnson RS. Autocrine VEGF isoforms differentially regulate endothelial cell behavior. Front Cell Dev Biol. 2016;4:99.

5. Xin $\mathrm{H}$, Zhong $\mathrm{C}$, Nudleman E, Ferrara N. Evidence for pro-angiogenic functions of VEGF-Ax. Cell. 2016;167(1):275-284.

6. Campochiaro PA, Aiello LP, Rosenfeld PJ. Anti-vascular endothelial growth factor agents in the treatment of retinal disease: From bench to bedside. Ophthalmology. 2016;123(10S):78-88.

7. Paradowska-Gorycka A, Pawlik A, Romanowska-Prochnicka K, et al. Relationship between VEGF gene polymorphisms and serum VEGF protein levels in patients with rheumatoid arthritis. PLoS One. 2016; 11(8):e0160769.

8. Heitrich M, García DM, Stoyanoff TR, Rodríguez JP, Todaro JS, Aguirre MV. Erythropoietin attenuates renal and pulmonary injury in polymicrobial induced-sepsis through EPO-R, VEGF and VEGFR2 modulation. Biomed Pharmacother. 2016;82:606-613.

9. Bulysheva AA, Hargrave B, Burcus N, Lundberg CL, Murray L, Heller RR. Vascular endothelial growth factor-A gene electrotransfer promotes angiogenesis in a porcine model of cardiac ischemia. Gene Ther. 2016;23(8-9):649-656.

10. García-Lucio J, Argemi G, Tura-Ceide O, et al. Gene expression profile of angiogenic factors in pulmonary arteries in COPD: Relationship with vascular remodeling. Am J Physiol Lung Cell Mol Physiol. 2016; 310(7):583-592. 
11. Wheler JJ, Janku F, Naing A, et al. TP53 alterations correlate with response to VEGF/VEGFR inhibitors: Implications for targeted therapeutics. Mol Cancer Ther. 2016;15(10):2475-2485.

12. Wojtukiewicz MZ, Sierko E, Skalij P, et al. Granulocyte-colony stimulating factor receptor, tissue factor, and VEGF-R bound VEGF in human breast cancer in loco. Adv Clin Exp Med. 2016;25(3):505-511.

13. Grzela K, Litwiniuk M, Krejner A, Zagorska W, Grzela T. Increased angiogenic factors in exhaled breath condensate of children with severe asthma: New markers of disease progression? Respir Med. 2016;118:119-121.

14. Lee KY, Lee KS, Park SJ, et al. Clinical significance of plasma and serum vascular endothelial growth factor in asthma. J Asthma. 2008;45(9): 735-739.

15. Lachheb J, Chelbi H, Dhifallah IB, et al. Association of vascular endothelial growth factor polymorphisms with asthma in Tunisian children. Gene Regul Syst Bio. 2008;2:89-96.

16. Pei $Q M$, Jiang $P$, Yang $M$, et al. Upregulation of a disintegrin and metalloproteinase-33 by VEGF in human airway smooth muscle cells: Implications for asthma. Cell Cycle. 2016;15(20):2819-2826.

17. Sharma S, Murphy AJ, Soto-Quiros ME, et al. Association of VEGF polymorphisms with childhood asthma, lung function and airway responsiveness. Eur Respir J. 2009;33(6):1287-1294.

18. Senger DR, Galli SJ, Dvorak AM, Perruzzi CA, Harvey VS, Dvorak HF. Tumor cells secrete a vascular permeability factor that promotes accumulation of ascites fluid. Science. 1983;219(4587):983-985.

19. Ferrara N, Henzel WJ. Pituitary follicular cells secrete a novel heparin-binding growth factor specific for vascular endothelial cells. Biochem Biophys Res Commun. 1989;161(2):851-858.
20. Czarniakowska-Bołtuć M, Ziętkowski Z, Bodzenta-Łukaszyk A. Rola wybranych czynników wzrostowych w astmie. Alergia Astma Immunol. 2012;17:172-179.

21. Meyer N, Akdis CA. Vascular endothelial growth factor as a key inducer of angiogenesis in the asthmatic airways. Curr Allergy Asthma Rep. 2013;13(1):1-9.

22. Li X, Wilson JW. Increased vascularity in the bronchial mucosa in mild asthma. Am J Respir Crit Care Med. 1997;156(1):229-233.

23. Lee C, Ma B, Takyar S, et al. Studies of vascular endothelial growth factor in asthma and chronic obstructive pulmonary disease. Proc Am Thorac Soc. 2011;8(6):512-515.

24. Koczy-Baron E, Kasperska-Zając A. Rola naczyniowo-śródbłonkowego czynnika wzrostu w procesach zapalnych. Postepy Hig Med Dosw (Online). 2014;68:57-65.

25. Barbato A, Turato G, Baraldo S, et al. Airway inflammation in childhood asthma. Am J Respir Crit Care Med. 2003;168(7):798-803.

26. Abdel-Rahman AM, el-Sahrigy SA, Bakr SI. A comparative study of two angiogenic factors: Vascular endothelial growth factor and angiogenin in induced sputum from asthmatic children in acute attack. Chest. 2006;129(2):266-271.

27. Asai K, Kanazawa H, Kamoi H, Shiraishi S, Hirata K, Yoshikawa J. Increased levels of vascular endothelial growth factor in induced sputum in asthmatic patients. Clin Exp Allergy. 2003;33(5):595-599.

28. Global Initiative for Asthma. Global Strategy for Asthma Management and Prevention 2017 (revision). https://ginasthma.org/wmsGINA-2017-main-report-tracked-changes-for-archive.pdf

29. Chebib R, Verlingue L, Cozic N, et al. Angiogenesis inhibition in the second-line treatment of metastatic colorectal cancer: A systematic review and pooled analysis. Semin Oncol. 2017;44(2):114-128.

30. Evans J, Virgili G. Anti-VEGF drugs: Evidence for effectiveness. Community Eye Health. 2014;27(87):48. 